\title{
Weathering, Soils and Paleosols, edited by I. P. Martini and W. Chesworth. Elsevier Science Publishers B. V., Amsterdam, The Netherlands, (1992), 618pp.
}

This book constitutes No. 2 of the series "Developments in Earth Surface Processes", with 28 contributors from Australia, Canada, France, New Zealand, Spain, Switzerland, U.K., and U.S.A. This book presents fresh viewpoints to the science of soils with a wide scope. Besides the main topics of soil science, that is, description of the constituents of soils and discussion on the genesis of soils, this book also sheds light on extraterrestrial soils, metallic mineralization in soils, diagenesis and metasomatism of soils, and the formation of paleosols. The main objective of this book seems to make readers realize soil as a constituent of the Earth.

The contents of this book is divided into six parts:

A. Introduction written by the two editors, both are of the University of Guelph, Canada, gives a short review on the subjects being discussed in this book. The importance of paleosols for the study of evolution of the biosphere is stressed. The editors say that many geologists have seldom seen soil as anything other than an inconvenient blanket, obscuring more important material, and that now an era has begun in which the geologists' attitude is changing, and many new and exciting scientific advances can be expected.

B. Processes on and near the Planetary Land Surface provides accounts of weathering systems, extraterrestrial soils, diagenetic and metasomatic changes of soils, and clay minerals and their formation. In the chapter of weathering systems, geochemical changes during weathering are discussed in terms of $\mathrm{pH}$ and $\mathrm{Eh}$. The chapter of incipient weathering written by French mineralogists is an outstanding review of the studies on incipient stage of clay mineral formation. In the chapter of diagenesis and metasomatism of weathering profiles, trends of changing chemical composition during dissolution of feldspars and mafic minerals are discussed using the triangular diagrams $\mathrm{Al}_{2} \mathrm{O}_{3}-$ $\left(\mathrm{CaO}+\mathrm{Na}_{2} \mathrm{O}\right)-\mathrm{K}_{2} \mathrm{O}$ and $\mathrm{Al}_{2} \mathrm{O}_{3}-\left(\mathrm{CaO}+\mathrm{Na}_{2} \mathrm{O}\right.$ $\left.+\mathrm{K}_{2} \mathrm{O}\right)-(\mathrm{FeO}+\mathrm{MgO})$, and actual compositional trends observed in paleosols are interpreted based on them.

C. The Present Land Surface of the Earth describes various soils developed on the present land surface, which include soils of the Alpine mountains, soils of cold climate regions, organic soils, desert soils, and soils in humid regions especially on igneous and metamorphic rocks.

D. Advanced Weathering Stages on Landscapes not Recently Affected by Tectonic or Glacial Activity gives an account of calcrete and silcrete, and important description and discussion on laterite. Metallic mineralization by weathering, e.g., gold concentration during lateritization, bauxite formation, concentration of Mn oxides and hydroxides, etc is also dealt with.

E. The Role of Paleosols in Interpreting Ancient Landscapes discusses paleosols from the viewpoint of geology, especially Paleozoic paleosols in connection with the evolution of life. In addition, this part contains description of underclay and related paleosols associated with coal.

F. Classification of Various Earth Materials is the final part of this book making classification of Earth materials from various standpoints.

This book will provide new views of soil to geologists, geochemists, and even to soil scientists, by considering soil as a geological body which has developed as a result of geological processes, geological history and evolution of environment. In part $\mathrm{D}$, for example, Tardy shows evidence for an intense lateritization that took 
place in Jurassic, Cretaceous and Eocene ages. face processes and the evolution of environment. That, along with other lines of geologic evidence, is of a great importance in discussing paleoclimatology.

Keinosuke Nagasawa

The reviewer believes that this book is very Tokoha-gakuen Hamamatsu University

1230 Miyakoda-machi, Hamamatsu 431-21, useful for those who are interested in earth's sur- Japan 